perpetual motion. That there are forces in nature which can and do produce it, is a matter of daily, yearly, and secular experience. If $I$ am a perpetual-motionist in this sense, $I$ am in good company. You will find that Sir W. Thomson, in the Philosophical Magazine for February 1854, described a machine by which a steam-engine or water-wheel could produce thirty-five times the heat commonly considered as equivalent to the force used ; or the corresponding amount of cold. At that time, then, two years after his paper read to the British Association (to which you refer me), he certainly did not hold such an opinion with regard to the mechanical equivalent of heat as to exclude the possibility of such an engine.

The final judgment of the question I confidently leave to time and facts. When any of the "grand founders of a rapidly progressive science" can spare time from their investigations to refute my fallacies, I shall gladly retract them.

H. HIGHTON

\section{The Spectrum of the Aurora}

In the sketch appended to my letter on this subject in last week's NATURE, I notice that the engraver has made the line at $4^{\prime} \mathrm{I}$ much too sharp and definite in both spectra. It really shades off rapidly to the more refrangible side, at least in the spectrum of the vacuum tube, and possibly also in that of the aurora. Though much the brightest line in the auroral spectrum, it is not the most conspicuous in that of the tube, but the relative brightness of lines frequently varies much at different temperatures. The band at 8 in the auroral spectrum is also repre. sented too narrow. Those who have practical experience with the spectroscope will appreciate the great difficulty of representing faint spectra correctly in a woodcut.

\section{Henry R. Procter}

\section{Science Teaching for the People}

THE subject of Science Teaching in our elementary schools having been ably brought forward by Mr. Henry Ullyett in a recentnumber of your Journal, and the scientific instruction under the Science and Art Department, South Kensington, having been at various times the subject of consideration in it, I venture to ask for a short space in your columns in order to submit the following proposition for the consideration of your readers, many of whom, have, probahly, special opportunities of coming to a correct judgment on the point. The question I wish solved is this: Is the spread of scientific education, under the auspices of the Science and Art Department, likely to be best promoted by the whole of the Department's assistance to any one town being dispensed by a single committee, by whom a central school shall be provided, of which all other schools established, or that may be established, in various districts of the town, shall be considered only as branches, and be subject to the control of the central committee, on whose books the names of all students would be borne, and through the one secretary of which all the returns and other communications to and from the Department would have to pass?

Is it not better that the schools established in various districts of a town, say in connection with each elementary school, should each have their separate organisation of committee and secretary, at least in so far as the teachers connected with each are different? In this town, in common with a great many others, the latter plan has been the rule, but a siggrestion has now been made that all these committees should be amalgamated, together with those of the art-classes also, the plea being that it might lead to the erection of a central building for the purposes of an art and science school.

Now, however necessary for art it is that there should be a central building for the provision of higher instruction than can be given in the night classes, I cannot see that there is anything in the study of science that demands gxeater facilities than can easily be provided by any district school, and the possession of which is indeed required by the Science Directory before any science school receives the approval of the Department.

Why, then, the science committees should be asked to unite in this town alone, by which a most dangerous precedent would be established, I cannot understand, for I do not believe that such a course would be beneficial to the town at large, while it would be very prejudicial to the interests of the existing district schools, and of any persons wishing to commence teaching in future.

Perhaps some of your realers will favour us with their views on the question I have stated, which I venture to think involves a principle of very general interest to the science schuols of the kingdom. a Member of a Science Commitie

\section{A Rare Moth}

Ir may be interesting to know that the rare and beautiful moth, Neilefhila Galii, appeared somewhat plentifully in the neighbourhood of Derby during the past summer. I have in my possession a fine male and female which were cap ured at Long Eaton, some few miles from Nottingham, whilst flying in company over a bed of geraniums. Is not this the first recorded instance of their appearance in this locality? Zezzera Esculi also appeared in unusual abundance in the same garden, upwards of fifty specimens being taken by one person. W. H. G.

\section{Measurement of Mass}

WILt, you allow me a few words in explanation of a sentence in my last letter, which has strangely been misunderstood by Prof. Everett. In defending the system which makes the standard pound a unit of force on the ground that although not the most philosophical, it simplifies the conception of ma $s$ which is always difficult for beginners, I said, "The assumption of a hypothetical force of gravity not dependent on latitude, seems to stand on the same footing as the employment of a mean solar day," meaning, of course, that just as we assume (for conn. venience) that a solar day is the same length at whatever pe: od of the year we take it, so we may assume a mean force of gravity (the actual force of gravity in latitude $45^{\circ}$ ) which is the same all over the earth. Such an assumption will enable us to explain the unfamiliar notion of mass by the familiar one of weight, and when it does become necessary to take into account the variation in the force of gravity at different points of the earth's surface, the correction is easily made.

Prof. Everett seems to think that I suppose that the average length of the apparent solar day is not the same at all places.on the earth. Will you allow me to quote the following passage from the original in support of my first assertion, that Prot. Everett's tacit assumption that everybody knows what mass is, is less likely to lead to clear ideas than the explanation given by Deschanel. He says-"Un corps a une masse plus grande qu'un autre lorsque la même force lui imprime une vitesse plus petite, et reciproquement, . . . . si nous considérons en particulier le poids d'un corps, on aura, entre ce poids, la masse et l'accélération de la pesanteur, la relation fondamentale,

$$
\mathrm{P}=\mathrm{M}_{\mathrm{g}}
$$

Cette formule nous montre que dans le même lieu le poids est proportionnel à la masse, parceque $g$ a la même valeur pour tous les corps. Il n'en est pas de même quand on passe d'un lieu à un autre ; mais comme après tout les variations sont extrếmement petires, en réaiité la masse et le poids sont deux quantités toujours sensibiement dans le même rapport. Toutefois il faut se rappeler que ces deux expressions correspondent à des notions distinctes; et, abstraction faite de toute évaluation numérique, la masse d'un corps est quelque chose qui lui est propre et qui est indépendant du poids. La pesanteur n'existerait pas qu'il n'en serait pas moins vrai qu'une sphère de plomb a une masse plus grande qu'une sphère de liége de même diamètre. Nous reconnaissons ce fait ordinairement à ce que la poids de la première sphère est plus grande que celui de la seconde; mais à défaut de la pesanteur, l'emploi de toute autre force pourrait nous conduire au mème resultat."

W. M. W.

\section{PHOTOGRAPHS OF THE ECLIPSE}

PERMIT me to call your attention to the position of the woodcut illustrating my remarks on the Eclipse Photographs. The south point is where the north should be. As what I have now to say refers to the picture I shall feel obliged if you will permit its reinsertion in its true position. * With reference to the power of the light of the Corona, I used the word actinic, not active as printed.

The readers of NATURE may perhaps be glad of the opportunity to compare for themselves tracings of the American and of my own photographs, which 1 now give in outline in illustration of remarks in your second article

* This vexing mistake was aue to a blunder of the printer in reversing the block afier it had been placed on the machine. Its re-inser.ion this week wil! rectify the mistake, $-E_{D}$. 